Article

\title{
Synthesis of Carvedilol-Organotin Complexes and Their Effects on Reducing Photodegradation of Poly(Vinyl Chloride)
}

\author{
Omar G. Mousa ${ }^{1}$, Gamal A. El-Hiti ${ }^{2, *}{ }^{6}$, Mohammed A. Baashen ${ }^{3}{ }^{(\mathbb{D}}$, Muna Bufaroosha ${ }^{4}$, Ahmed Ahmed ${ }^{5}$, \\ Ahmed A. Ahmed ${ }^{1}$, Dina S. Ahmed ${ }^{6}$ and Emad Yousif ${ }^{1}(\mathbb{D}$ \\ 1 Department of Chemistry, College of Science, Al-Nahrain University, Baghdad 64021, Iraq; \\ omarchemistry1987@gmail.com (O.G.M.); ahmedahmedalazawi@gmail.com (A.A.A.); \\ emad_yousif@hotmail.com (E.Y.) \\ 2 Cornea Research Chair, Department of Optometry, College of Applied Medical Sciences, King Saud \\ University, P.O. Box 10219, Riyadh 11433, Saudi Arabia \\ 3 Department of Chemistry, College of Science and Humanities, Shaqra University, Dawadmi 11911, Saudi \\ Arabia; mbaashen@su.edu.sa \\ 4 Department of Chemistry, College of Science, United Arab Emirates University, P.O. Box 15551 \\ Al-Ain 1818, United Arab Emirates; muna.bufaroosha@uaeu.ac.ae \\ 5 Polymer Research Unit, College of Science, Al-Mustansiriyah University, Baghdad 10052, Iraq; \\ drahmed625@gmail.com \\ 6 Department of Medical Instrumentation Engineering, Al-Mansour University College, Baghdad 10067, Iraq; \\ dinasaadi86@gmail.com \\ * Correspondence: gelhiti@ksu.edu.sa; Tel.: +966-11469-3778; Fax: +966-11469-3536
}

Citation: Mousa, O.G.; El-Hiti, G.A.; Baashen, M.A.; Bufaroosha, M.; Ahmed, A.; Ahmed, A.A.; Ahmed, D.S.; Yousif, E. Synthesis of Carvedilol-Organotin Complexes and Their Effects on Reducing Photodegradation of Poly(Vinyl Chloride). Polymers 2021, 13, 500. https://doi.org/10.3390/polym 13040500

Academic Editors: Nadka

Tz. Dintcheva and

Mariaenrica Frigione

Received: 23 December 2020

Accepted: 3 February 2021

Published: 6 February 2021

Publisher's Note: MDPI stays neutral with regard to jurisdictional claims in published maps and institutional affiliations.

Copyright: () 2021 by the authors. Licensee MDPI, Basel, Switzerland. This article is an open access article distributed under the terms and conditions of the Creative Commons Attribution (CC BY) license (https:// creativecommons.org/licenses/by/ $4.0 /)$
Abstract: Poly(vinyl chloride) (PVC) undergoes photodegradation induced by ultraviolet (UV) irradiation; therefore, for outdoor applications, its photostability should be enhanced through the use of additives. Several carvedilol tin complexes were synthesized, characterized and mixed with PVC to produce thin films. These films were irradiated at $25^{\circ} \mathrm{C}$ with a UV light $(\lambda=313 \mathrm{~nm})$ for up to $300 \mathrm{~h}$. The reduction in weight and changes in chemical structure and surface morphology of the PVC films were monitored. The films containing synthesized complexes showed less undesirable changes than the pure PVC film. Organotin with a high content of aromatics was particularly efficient in inhibiting photodegradation of PVC. The carvedilol tin complexes both absorbed UV light and scavenged radicals, hydrochloride, and peroxides and, therefore, photostabilized PVC.

Keywords: carvedilol-tin complexes; poly(vinyl chloride); photostabilizers; surface morphology; weight loss; functional group indices

\section{Introduction}

Poly(vinyl chloride) (PVC) has numerous industrial applications [1]. It is one of the three most manufactured thermoplastics [2]. PVC has received considerable attention due to its low cost, long duration, good mechanical and chemical stability, ease of molding, and ability to be produced in different forms (rigid and flexible) [3,4]. It is widely used for the production of items such as medical equipment, toys, construction materials, food packaging, and disposable blood bags [2]. It is considered to be an excellent alternative to glass and wood in many applications [5].

PVC undergoes autocatalytic dehydrochlorination when exposed to a high temperature. This results in the formation of conjugated double bonds because of the elimination of hydrogen chloride ( $\mathrm{HCl}$ ) [6]. Therefore, the photostability of PVC is poor, and it must be mixed with appropriate photostabilizers to inhibit its decomposition and photooxidation. Various types of thermal stabilizers are used for PVC [7]. Recent research has focused on the production and use of organic PVC photostabilizers that are inexpensive to produce, can be used at low concentrations, and are non-toxic. Various types of small molecules are mixed with PVC to serve as photostabilizers and photoabsorbers. Such molecules can 
protect PVC from surface cracking, discoloration, and changes in mechanical properties under long periods of exposure to sunlight [8-10].

Recently, various additives, including polyphosphates [9,10], aromatics [11,12], Schiff bases [11-19], pigments [20], inorganic salts [21,22], and organotin complexes [23-29] have been tested for their efficiency as inhibitors of PVC photodegradation and photooxidation. Organotin complexes are highly stable, have distinctive properties, and are useful materials in numerous applications [30,31]. Carvedilol is available commercially, it is inexpensive, ecofriendly, non-toxic, and highly aromatic, and it contains heteroatoms (nitrogen and oxygen). These properties make carvedilol a good ligand for coordination with tin to produce effective PVC additives. This study reports the synthesis and characterization of new carvedilol tin complexes. These complexes are non-volatile, cause no change in color, are compatible with polymeric materials, can be used at a low concentration, and have been tested as inhibitors of PVC photodegradation under exposure to UV light.

\section{Materials and Methods}

\subsection{General}

Triphenyltin chloride $\left(95 \% ; \mathrm{Ph}_{3} \mathrm{SnCl}\right)$, dibutyltin oxide $\left(98 \%\right.$; $\left.\mathrm{Bu}_{2} \mathrm{SnO}\right)$, dibutyltin dichloride $\left(96 \% ; \mathrm{Bu}_{2} \mathrm{SnCl}_{2}\right)$, dimethyltin dichloride $\left(97 \% ; \mathrm{Me}_{2} \mathrm{SnCl}_{2}\right)$, carvedilol $(98 \%)$, and solvent were supplied by Merck (Gillingham, UK). The PVC $\left(\bar{M}_{V}=c a .250,000\right)$ was obtained from Petkim Petrokimya (Istanbul, Turkey). The FTIR spectra were recorded on a Shimadzu FTIR 8300 spectrophotometer(Shimadzu, Tokyo, Japan). The ${ }^{1} \mathrm{H}(500 \mathrm{MHz}),{ }^{13} \mathrm{C}$ $(125 \mathrm{MHz})$, and ${ }^{119} \mathrm{Sn}$ NMR (149 MHz) spectra were recorded on a Bruker DRX500 MHz spectrometer. The conductivity was measured on a WTW ProfiLine Oxi 3205 conventional portable meter in dimethyl sulfoxide $\left(10^{-3} \mathrm{~mole} / \mathrm{L}\right)$ at $25^{\circ} \mathrm{C}$ (Geotech, Barcelona, Spain). The PVC optical images were captured using a Meiji Techno Microscope (Tokyo, Japan). A Veeco system was used to examine the surface morphology of PVC films. An accelerated weather-meter QUV tester was used to irradiate the PVC films using UV light with $\lambda_{\max }$ of

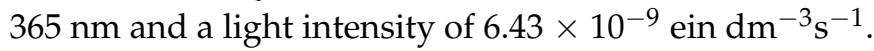

\subsection{Synthesis of Organotin Complexes 1 and $\mathbf{2}$}

A mixture of carvedilol $(0.41 \mathrm{~g}, 1.0 \mathrm{mmol})$ and either triphenyltin chloride $\left(\mathrm{Ph}_{3} \mathrm{SnCl}\right.$; $0.39 \mathrm{~g}, 1.0 \mathrm{mmol})$ or dibutyltin oxide $\left(\mathrm{Bu}_{2} \mathrm{SnO} ; 0.25 \mathrm{~g}, 1.0 \mathrm{mmol}\right)$ in methanol $(\mathrm{MeOH}$, $15 \mathrm{~mL}$ ) was refluxed either for six or eight hours, respectively. The solvent was removed under vacuum and the solid produced was recrystallized from $\mathrm{MeOH}$ to yield a white powder of either of the organotin complexes $\mathbf{1}$ or 2.

\subsection{Synthesis of Organotin Complexes 3 and 4}

A mixture of carvedilol $(0.81 \mathrm{~g}, 2.0 \mathrm{mmol})$ and dialkyltin chloride $(1.0 \mathrm{mmol})$ in $\mathrm{MeOH}$ $(20 \mathrm{~mL})$ was refluxed for eight hours. The solvent was removed under reduced pressure and the solid produced was recrystallized from $\mathrm{MeOH}$ to yield a white powder of either of the organotin complexes 3 or 4 .

\subsection{Preparation of PVC Films}

Organotin complexes $(25 \mathrm{mg}$ ) were added to a stirred solution of PVC (5 g) in tetrahydrofuran (THF; $100 \mathrm{~mL}$ ). The mixture was stirred for three hours at $25^{\circ} \mathrm{C}$. The homogenous solution obtained was transferred onto glass plates containing holes (thickness $=40 \mu \mathrm{m}$ ) and left to dry at room temperature for $24 \mathrm{~h}$ and subsequently left at reduced pressure for eight hours.

\subsection{Characterization of PVC Photodegradation Using FTIR Spectrophotometry}

The progress of the photodegradation of the PVC was monitored using FTIR spectroscopy. The increases in the absorption of several functional groups as a function of irradiation time were recorded for the PVC films. The indices of functional groups (Is) were calculated using Equation (1) based on the absorbance of the peaks of corresponding 
functional groups $(A s)$ and that of a reference group $(A r)$ that is not affected by irradiation $\left(\mathrm{CH}_{2}\right)$ [32].

$$
I_{s}=A_{s} / A_{r}
$$

\subsection{Monitoring of PVC Photodegradation Using Weight Loss}

PVC photodegradation results in the elimination of volatiles and, therefore, weight loss. The percentage of weight loss can be calculated from the weight of PVC before $\left(W_{1}\right)$ and after irradiation $\left(W_{2}\right)$ using Equation (2) [27].

$$
\text { Weight loss }(\%)=\left[\left(W_{1}-W_{2}\right) / W_{0}\right] \times 100
$$

\section{Results and Discussion}

\subsection{Synthesis of Tin Complexes 1-4}

The reaction of carvedilol and either triphenyltin chloride or dibutyltin oxide at a 1:1 ratio in boiling methanol produced the tin complexes $\mathbf{1}$ or $\mathbf{2}$, respectively (Scheme 1), as a white solid. On the other hand, the reaction of carvedilol and appropriate dialkyltin chloride at a 2:1 ratio under similar conditions produced the tin complexes 3 or 4, respectively (Scheme 2), as a white solid. No base was used in the synthesis of complexes 1-4 which agrees with previously reported procedures [33-35]. Table 1 displays the yields, melting points, and elemental analyses (found and calculated \%) for 1-4.
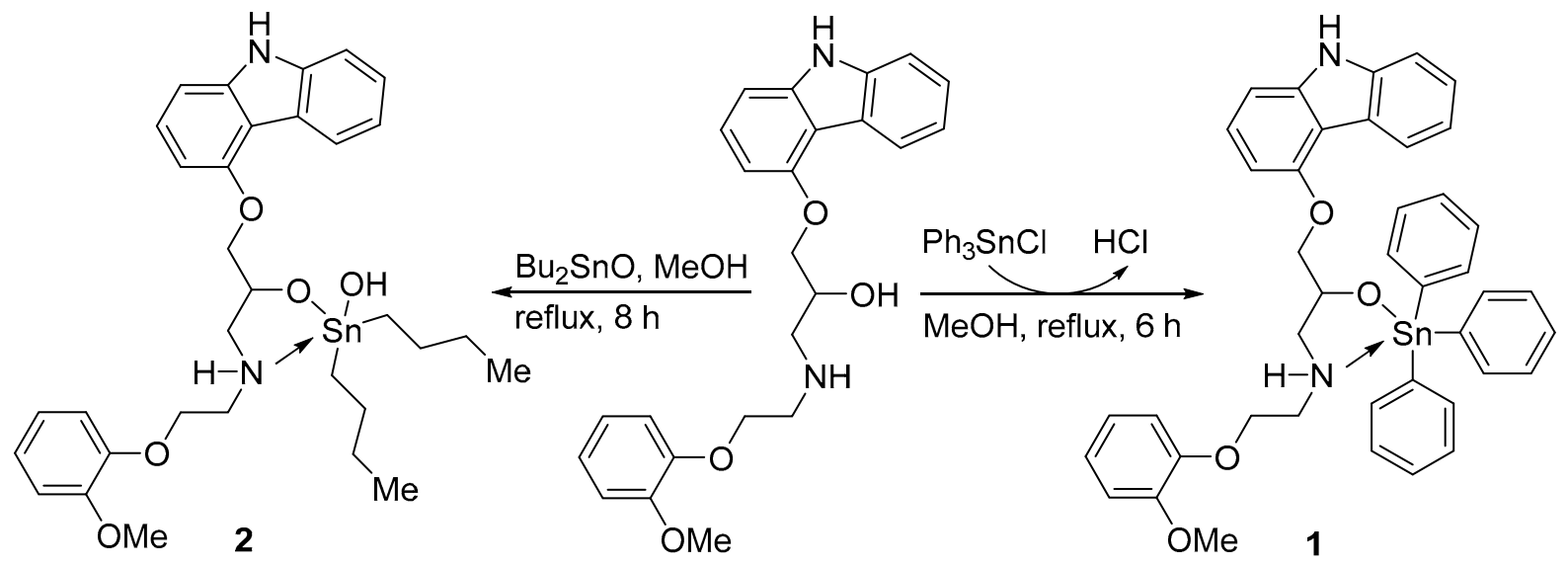

Scheme 1. Synthesis of 1 and 2.
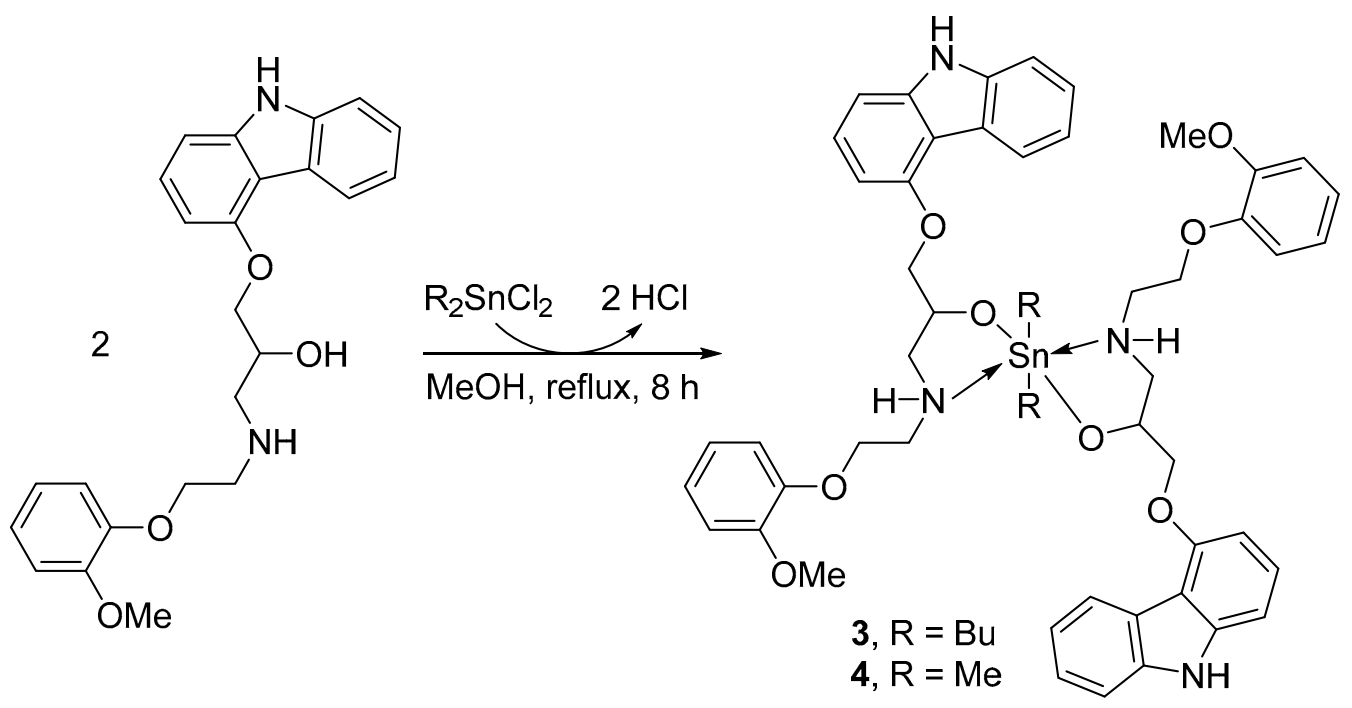

Scheme 2. Synthesis of 3 and 4. 
Table 1. Yields, melting points, and elemental analyses for 1-4.

\begin{tabular}{ccccccc}
\hline \multirow{2}{*}{ Complex } & \multirow{2}{*}{ Yield (\%) } & \multirow{2}{*}{ MP $\left({ }^{\circ} \mathbf{C}\right)$} & \multicolumn{4}{c}{ Elemental Analyses (\%) Found (Calculated) } \\
\cline { 4 - 7 } & & & $\mathbf{C}$ & $\mathbf{H}$ & $\mathbf{N}$ & Sn \\
\hline $\mathbf{1}$ & 75 & $121-123$ & $66.86(66.77)$ & $5.328(5.34)$ & $3.65(3.71)$ & $15.58(15.71)$ \\
$\mathbf{2}$ & 73 & $110-113$ & $58.56(58.64)$ & $6.70(6.77)$ & $4.19(4.27)$ & $18.01(18.11)$ \\
$\mathbf{3}$ & 71 & $88-90$ & $64.30(64.43)$ & $6.51(6.57)$ & $5.29(5.37)$ & $12.23(11.37)$ \\
$\mathbf{4}$ & 70 & $108-111$ & $62.52(62.57)$ & $5.85(5.88)$ & $5.71(5.84)$ & $12.23(12.37)$ \\
\hline
\end{tabular}

The FTIR spectra of 1-4 exhibited absorption bands resulting from the formation of Sn$\mathrm{C}\left(536-540 \mathrm{~cm}^{-1}\right), \mathrm{Sn}-\mathrm{O}\left(466-474 \mathrm{~cm}^{-1}\right)$, and Sn-N $\left(424-447 \mathrm{~cm}^{-1}\right)$ bonds which agree with those reported for organotin compounds $[35,36]$. Furthermore, they exhibited absorption bands for the aromatic and aliphatic N-H bonds at 3340-3410 and 3201-3294 cm ${ }^{-1}$, respectively. The high shift in stretching frequency of aliphatic $\mathrm{N}-\mathrm{H}$ indicated the occurrence of coordination between tin and nitrogen atoms in carvedilol. Table 2 displays selected FTIR spectral data for $\mathbf{1 - 4}$.

Table 2. Selected FTIR data for and 1-4.

\begin{tabular}{cccccc}
\hline \multirow{2}{*}{ Complex } & \multicolumn{5}{c}{ Wave Number $\left(v, \mathbf{c m}^{\mathbf{- 1}}\right)$} \\
\cline { 2 - 6 } & NH (Ar) & NH (Ali) & Sn-C & Sn-O & Sn-N \\
\hline Carvedilol & 3345 & 3059 & - & - & - \\
$\mathbf{1}$ & 3410 & 3294 & 536 & 466 & 447 \\
$\mathbf{2}$ & 3340 & 3201 & 543 & 466 & 439 \\
$\mathbf{3}$ & 3398 & 3290 & 540 & 474 & 435 \\
$\mathbf{4}$ & 3402 & 3236 & 540 & 474 & 424 \\
\hline
\end{tabular}

The ${ }^{1} \mathrm{H}$ NMR spectra of 1-4 showed the absence of the $\mathrm{OH}$ proton that appeared at $5.21 \mathrm{ppm}$ in the ${ }^{1} \mathrm{H}$ NMR spectrum of carvedilol, thus confirming the formation of the complexes. ${ }^{1} \mathrm{H}$ NMR spectra revealed the presence of two exchangeable singlets that appeared within the $8 \mathrm{ppm}$ and $2 \mathrm{ppm}$ regions because of the aromatic and aliphatic $\mathrm{NH}$ protons, respectively (Table 3).

Table 3. ${ }^{1} \mathrm{H}$ NMR data for and 1-4.

\begin{tabular}{|c|c|}
\hline Complex & ppm, Hz (DMSO- $\left.d_{6}\right)$ \\
\hline Carvedilol & $\begin{array}{r}11.28(\mathrm{~s}, 1 \mathrm{H}, \mathrm{NH}), 8.29(\mathrm{~d}, J=8.1 \mathrm{~Hz}, 1 \mathrm{H}, \mathrm{Ar}), 7.50(\mathrm{~d}, J=8.1 \mathrm{~Hz}, 1 \mathrm{H}, \mathrm{Ar}), 7.38(\mathrm{t}, J=8.1 \mathrm{~Hz}, 1 \mathrm{H}, \mathrm{Ar}), 7.35(\mathrm{~d}, \\
J=8.1 \mathrm{~Hz}, 1 \mathrm{H}, \mathrm{Ar}), 7.31(\mathrm{~d}, J=8.1 \mathrm{~Hz}, 1 \mathrm{H}, \mathrm{Ar}), 7.18(\mathrm{t}, J=8.1 \mathrm{~Hz}, 1 \mathrm{H}, \mathrm{Ar}), 7.12(\mathrm{~d}, J=8.1 \mathrm{~Hz}, 1 \mathrm{H}, \mathrm{Ar}), 6.95-6.71 \\
(\mathrm{~m}, 4 \mathrm{H}, \mathrm{Ar}), 5.21(\mathrm{~s}, \text { exch., } 1 \mathrm{H}, \mathrm{NH}), 4.23-4.16\left(\mathrm{~m}, 4 \mathrm{H}, \mathrm{OH}, \mathrm{CH}_{2} \text { and } \mathrm{CH}\right), 4.03\left(\mathrm{t}, J=7.1 \mathrm{~Hz}, 2 \mathrm{H}, \mathrm{CH}_{2}\right), 3.75(\mathrm{~s}, \\
\text { 3H, OMe }), 2.97\left(\mathrm{~m}, 2 \mathrm{H}, \mathrm{CH}_{2}\right), 2.01(\mathrm{~s}, 1 \mathrm{H}, \mathrm{NH})\end{array}$ \\
\hline 1 & $\begin{array}{c}11.28(\mathrm{~s}, 1 \mathrm{H}, \mathrm{NH}), 8.28(\mathrm{~d}, J=8.0 \mathrm{~Hz}, 1 \mathrm{H}, \mathrm{Ar}), 7.90-7.82(\mathrm{~m}, 5 \mathrm{H}, \mathrm{Ar}), 7.49-7.32(\mathrm{~m}, 10 \mathrm{H}, \mathrm{Ar}), 7.28-7.11(\mathrm{~m}, 4 \mathrm{H}, \\
\mathrm{Ar}), 6.98-6.86(\mathrm{~m}, 5 \mathrm{H}, \mathrm{Ar}), 6.72(\mathrm{~d}, J=8.0 \mathrm{~Hz}, 1 \mathrm{H}, \mathrm{Ar}), 4.25-4.22\left(\mathrm{~m}, 3 \mathrm{H}, \mathrm{CH}_{2} \text { and CH}\right), 4.07-4.02\left(\mathrm{~m}, 2 \mathrm{H}, \mathrm{CH}_{2}\right), \\
3.75(\mathrm{~s}, 3 \mathrm{H}, \mathrm{OMe}), 3.00-2.88\left(\mathrm{~m}, 4 \mathrm{H}, 2 \mathrm{CH}_{2}\right), 2.10(\mathrm{~s}, 1 \mathrm{H}, \mathrm{NH})\end{array}$ \\
\hline 2 & $\begin{array}{c}11.28(\mathrm{~s}, 1 \mathrm{H}, \mathrm{NH}), 7.80(\mathrm{~d}, J=8.0 \mathrm{~Hz}, 1 \mathrm{H}, \mathrm{Ar}), 7.00(\mathrm{~d}, J=8.0 \mathrm{~Hz}, 1 \mathrm{H}, \mathrm{Ar}), 6.87-7.82(\mathrm{~m}, 2 \mathrm{H}, \mathrm{Ar}), 6.69-6.62(\mathrm{~m}, \\
2 \mathrm{H}, \mathrm{Ar}), 6.52-6.40(\mathrm{~m}, 4 \mathrm{H}, \mathrm{Ar}), 6.25(\mathrm{~d}, J=8.0 \mathrm{~Hz}, 1 \mathrm{H}, \mathrm{Ar}), 4.73(\mathrm{~s}, 1 \mathrm{H}, \mathrm{OH}), 3.77-3.60\left(\mathrm{~m}, 7 \mathrm{H}, 3 \mathrm{CH}_{2} \text { and } \mathrm{CH}\right), \\
\left.\text { 3.24-3.08 (m, } 6 \mathrm{H}, 3 \mathrm{CH}_{2}\right), 3.30(\mathrm{~s}, 3 \mathrm{H}, \mathrm{OMe}), 2.91\left(\mathrm{~m}, 4 \mathrm{H}, 2 \mathrm{CH}_{2}\right), 2.11(\mathrm{~s}, 1 \mathrm{H}, \mathrm{NH}), 1.35\left(\mathrm{~m}, 4 \mathrm{H}, 2 \mathrm{CH}_{2}\right), 0.98(\mathrm{t}, \\
J=7.5 \mathrm{~Hz}, 6 \mathrm{H}, 2 \mathrm{Me})\end{array}$ \\
\hline 3 & $\begin{array}{c}11.36(\mathrm{~s}, 2 \mathrm{H}, 2 \mathrm{NH}), 8.26(\mathrm{~d}, J=8.0 \mathrm{~Hz}, 2 \mathrm{H}, \mathrm{Ar}), 7.49(\mathrm{~d}, J=8.0 \mathrm{~Hz}, 2 \mathrm{H}, \mathrm{Ar}), 7.38-7.31(\mathrm{~m}, 4 \mathrm{H}, \mathrm{Ar}), 7.15-7.06(\mathrm{~m}, \\
4 \mathrm{H}, \mathrm{Ar}), 7.01-6.93(\mathrm{~m}, 8 \mathrm{H}, \mathrm{Ar}), 6.73(\mathrm{~d}, J=8.0 \mathrm{~Hz}, 2 \mathrm{H}, \mathrm{Ar}), 4.35-4.23\left(\mathrm{~m}, 6 \mathrm{H}, 2 \mathrm{CH}_{2} \text { and } 2 \mathrm{CH}\right), 3.75(\mathrm{~s}, 6 \mathrm{H}, 2 \\
\mathrm{OMe}), 3.28-3.10\left(\mathrm{~m}, 4 \mathrm{H}, 2 \mathrm{CH}_{2}\right), 2.10(\mathrm{~s}, 2 \mathrm{H}, 2 \mathrm{NH}), 1.79\left(\mathrm{~m}, 8 \mathrm{H}, 4 \mathrm{CH}_{2}\right), 1.70\left(\mathrm{~m}, 4 \mathrm{H}, 2 \mathrm{CH}_{2}\right), 1.57-1.53(\mathrm{~m}, 4 \mathrm{H}, \\
\left.2 \mathrm{CH}_{2}\right), 1.33\left(\mathrm{t}, J=7.6 \mathrm{~Hz}, 4 \mathrm{H}, 2 \mathrm{CH}_{2}\right), 0.87(\mathrm{t}, J=7.6 \mathrm{~Hz}, 6 \mathrm{H}, 2 \mathrm{Me})\end{array}$ \\
\hline 4 & $\begin{array}{c}11.37(\mathrm{~s}, 2 \mathrm{H}, 2 \mathrm{NH}), 8.27(\mathrm{~d}, J=8.1 \mathrm{~Hz}, 2 \mathrm{H}, \mathrm{Ar}), 7.50(\mathrm{~d}, J=8.1 \mathrm{~Hz}, 2 \mathrm{H}, \mathrm{Ar}), 7.39-7.31(\mathrm{~m}, 6 \mathrm{H}, \mathrm{Ar}), 7.16-7.12(\mathrm{~m}, \\
4 \mathrm{H}, \mathrm{Ar}), 7.03-6.89(\mathrm{~m}, 6 \mathrm{H}, \mathrm{Ar}), 6.74(\mathrm{~d}, J=8.1 \mathrm{~Hz}, 2 \mathrm{H}, \mathrm{Ar}), 4.41-4.15\left(\mathrm{~m}, 6 \mathrm{H}, 2 \mathrm{CH}_{2} \text { and } 2 \mathrm{CH}\right), 3.83-3.74(\mathrm{~m}, 6 \mathrm{H}, \\
\left.\quad 3 \mathrm{CH}_{2}\right), 3.59(\mathrm{~s}, 6 \mathrm{H}, 2 \mathrm{OMe}), 3.32-3.19\left(\mathrm{~m}, 6 \mathrm{H}, 3 \mathrm{CH}_{2}\right), 2.32(\mathrm{~s}, 2 \mathrm{H}, 2 \mathrm{NH}), 0.84(\mathrm{~s}, 6 \mathrm{H}, 2 \mathrm{Me})\end{array}$ \\
\hline
\end{tabular}

The ${ }^{13} \mathrm{C}$ NMR spectra of 1-4 showed all the carbon atoms within the complexes (Table 4). The ${ }^{119} \mathrm{Sn}$ NMR spectra of $\mathbf{1}(-136.2 \mathrm{ppm})$ and $\mathbf{2}(-196.5 \mathrm{ppm})$ confirmed that 
the geometry of these complexes is penta-coordinated. Conversely, the geometry of both 3 $(-341.8 \mathrm{ppm})$ and $4(-213.8 \mathrm{ppm})$ is hexa-coordinated (Table 4$)$. The ${ }^{119} \mathrm{Sn}$ chemical shifts are different for complexes with geometries involving four ( +200 to $-60 \mathrm{ppm})$, five ( -90 to $-190 \mathrm{ppm}$ ), and six coordination numbers ( -210 to $-400 \mathrm{ppm}$ ) [37-39].

Table 4. ${ }^{13} \mathrm{C}$ and ${ }^{119} \mathrm{Sn}$ NMR data for carvedilol and 1-4.

\begin{tabular}{|c|c|c|}
\hline \multirow{2}{*}{ Complex } & \multicolumn{2}{|l|}{ NMR (ppm, Hz, DMSO- $\left.d_{6}\right)$} \\
\hline & ${ }^{13} \mathrm{C}$ & ${ }^{119} \mathrm{Sn}$ \\
\hline Carvedilol & $\begin{array}{c}156.0,149.3,148.2,141.2,139.0,126.5,124.5,122.4,121.8,121.0,120.7,118.6,113.8,112.3 \\
111.7,110.3,103.8,100.5,70.5,68.5,55.5,52.6,48.6\end{array}$ & - \\
\hline 1 & $\begin{array}{c}155.0,149.3,148.1,141.2,139.0,136.2,135.8,129.0,128.1,126.5,124.5,122.5,121.8,121.1 \\
120.7,118.6,113.9,112.3,111.6,110.3,103.9,100.5,70.5,68.4,68.3,55.5,52.5,48.8\end{array}$ & -136.2 \\
\hline 2 & $\begin{array}{c}154.5,148.8,147.7,140.7,138.5,126.0,124.0,122.0,121.3,120.6,120.3,118.1,113.4,111.9, \\
111.2,109.9,104.4,100.0,70.0,68.1,68.0,55.0,52.2,48.1,32.0,27.5,26.3,13.5\end{array}$ & -169.5 \\
\hline 3 & $\begin{array}{c}155.8,149.0,147.6,141.2,139.0,126.5,124.5,122.5,121.7,120.7,120.5,118.6,114.4,112.3 \\
111.6,110.4,104.0,100.5,70.2,68.2,68.0,55.4,51.5,47.8,39.2,26.7,25.8,13.7\end{array}$ & -341.8 \\
\hline 4 & $\begin{array}{c}154.8,149.2,148.0,141.2,139.0,126.5,124.6,122.5,121.7,120.7,120.5,118.6,114.8,112.3 \\
111.6,110.4,104.1,100.5,70.1,66.3,66.2,55.4,51.2,46.6,6.7\end{array}$ & -213.8 \\
\hline
\end{tabular}

The molar conductivity $\left(10^{-3} \mathrm{M}\right.$; ethanol) for $1(2.7 \mu \mathrm{S} / \mathrm{cm}), 2(5.4 \mu \mathrm{S} / \mathrm{cm}), 3$ $(3.5 \mu \mathrm{S} / \mathrm{cm})$, and $4(4.8 \mu \mathrm{S} / \mathrm{cm})$ confirmed that these complexes are non-electrolytic (less than $100 \mu \mathrm{S} / \mathrm{cm}$ ) [40-42].

\subsection{PVC Photodegradation Using FTIR Spectroscopy}

Irradiation causes photooxidation of PVC and promotes the formation of small fragments containing ketones, polyene, and alcohol. The absorbance and intensity of the functional groups corresponding to these fragments can be monitored with FTIR spectroscopy $[43,44]$. Tin complexes $1-4$ were mixed with PVC at a concentration of $0.5 \%$ by weight and casted to thin $(40 \mu \mathrm{m})$ polymeric films. The films were exposed to light with a wavelength of $313 \mathrm{~cm}^{-1}$ at $25^{\circ} \mathrm{C}$ for up to $300 \mathrm{~h}$. After each 50-h period of irradiation, we recorded the FTIR spectra for the irradiated films. The growth in intensity of $\mathrm{C}=\mathrm{C}$ (alkenes; $1604 \mathrm{~cm}^{-1}$ ), $\mathrm{C}=\mathrm{O}$ (ketones; $1772 \mathrm{~cm}^{-1}$ ), and $\mathrm{OH}$ (alcohols; $3500 \mathrm{~cm}^{-1}$ ) peaks were monitored and compared with a reference peak $\left(\mathrm{CH}_{2} ; 1328 \mathrm{~cm}^{-1}\right)$ [45-47]. Figure 1 displays the FTIR spectra of pure PVC film before and after irradiation for 300 hours. It shows that after irradiation, the intensity of $\mathrm{C}=\mathrm{C}, \mathrm{C}=\mathrm{O}$, and $\mathrm{OH}$ peaks in the FTIR spectra increased significantly compared to that before irradiation. Equation (1) to calculate the functional group indices $\left(I_{\mathrm{C}=\mathrm{C}}, I_{\mathrm{C}=\mathrm{O}}\right.$, and $\left.I_{\mathrm{OH}}\right)$. Figure 2 shows the changes in these indices as a function of time (hours).

The $I_{\mathrm{C}=\mathrm{C}}, I_{\mathrm{C}=\mathrm{O}}$, and $I_{\mathrm{OH}}$ of pure PVC film were higher than those of the blends containing additives 1-4. As the duration of irradiation increased, the functional group indices increased steadily and gradually. The $I_{\mathrm{C}=\mathrm{C}}$ for $\mathrm{PVC}$ films, before irradiation was 0.04, and it had increased to 0.41 (blank PVC), 0.24 (PVC/1 blend), 0.30 (PVC/ 2 blend), 0.28 ( $\mathrm{PVC} / 3$ blend), and 0.34 (PVC/4 blend), after irradiation. After irradiation (300 hours), the index in the $\mathrm{C}=\mathrm{O}$ group had increased from 0.05 to 0.41 (blank PVC), 0.24 (PVC / 1 blend), 0.31 (PVC/ 2 blend), 0.27 (PVC/3 blend), and 0.33 (PVC/ 4 blend). Similar increases in the $I_{\mathrm{OH}}$ (from 0.04 to 0.31 ) were seen after irradiation. The highly aromatic additive, 1, was the most effective complex in inhibiting the irradiation-induced growth of functional group indices for PVC; this was followed the additives 3, 2, and 4, in that order. The phenyl rings within 1 act as a good UV absorber and can convert harmful irradiation to harmless heat [14]. 


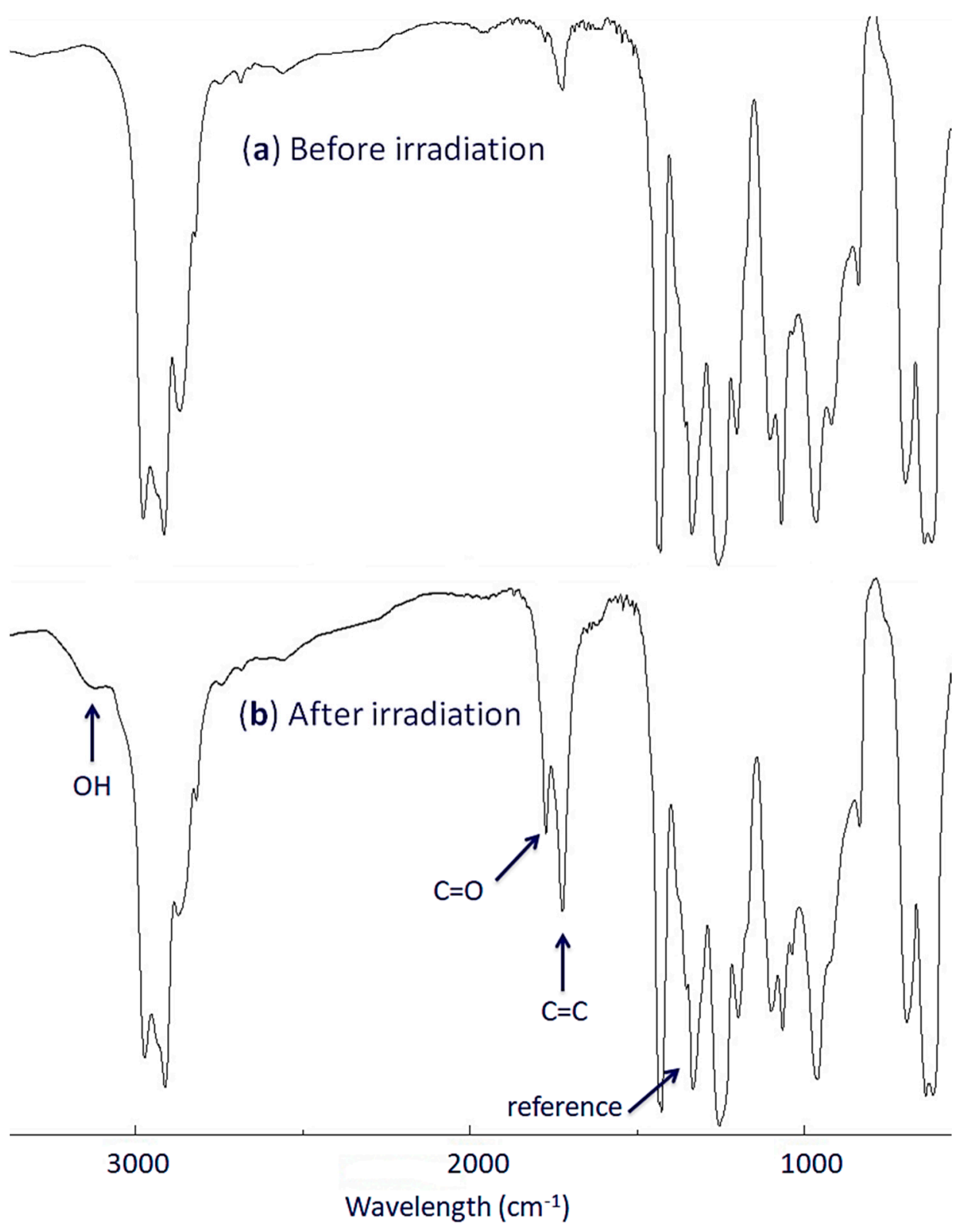

Figure 1. FTIR spectra of PVC: (a) before irradiation and (b) after irradiation. 
(a)

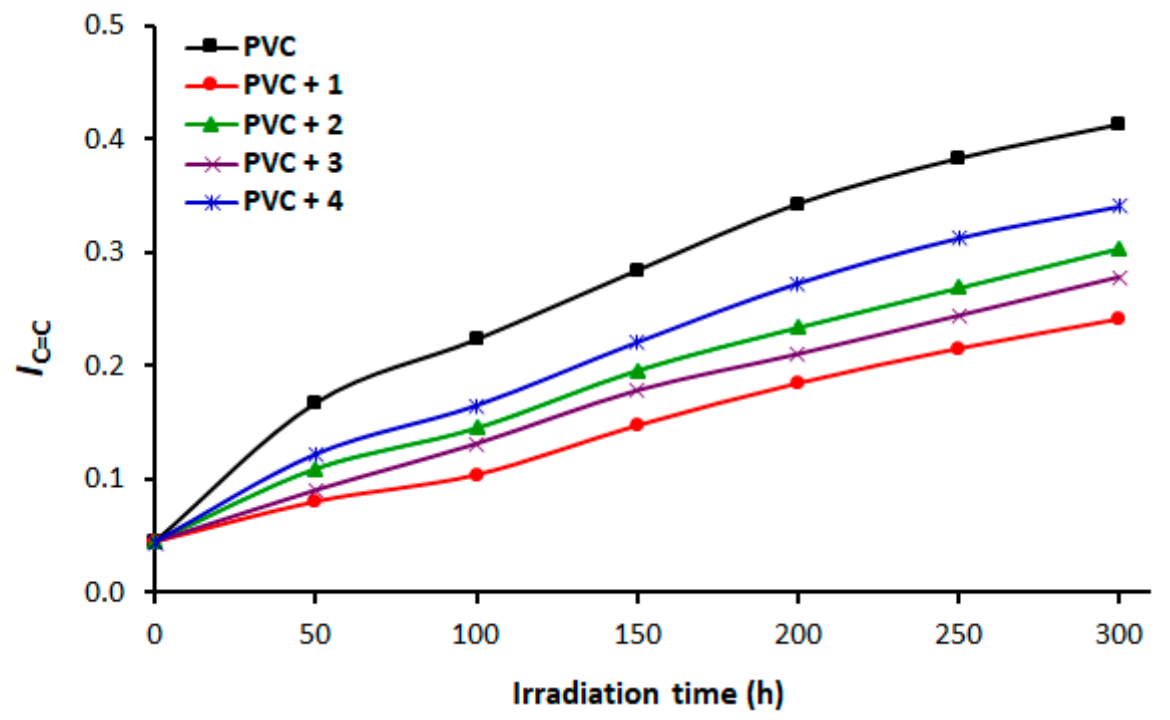

(b)

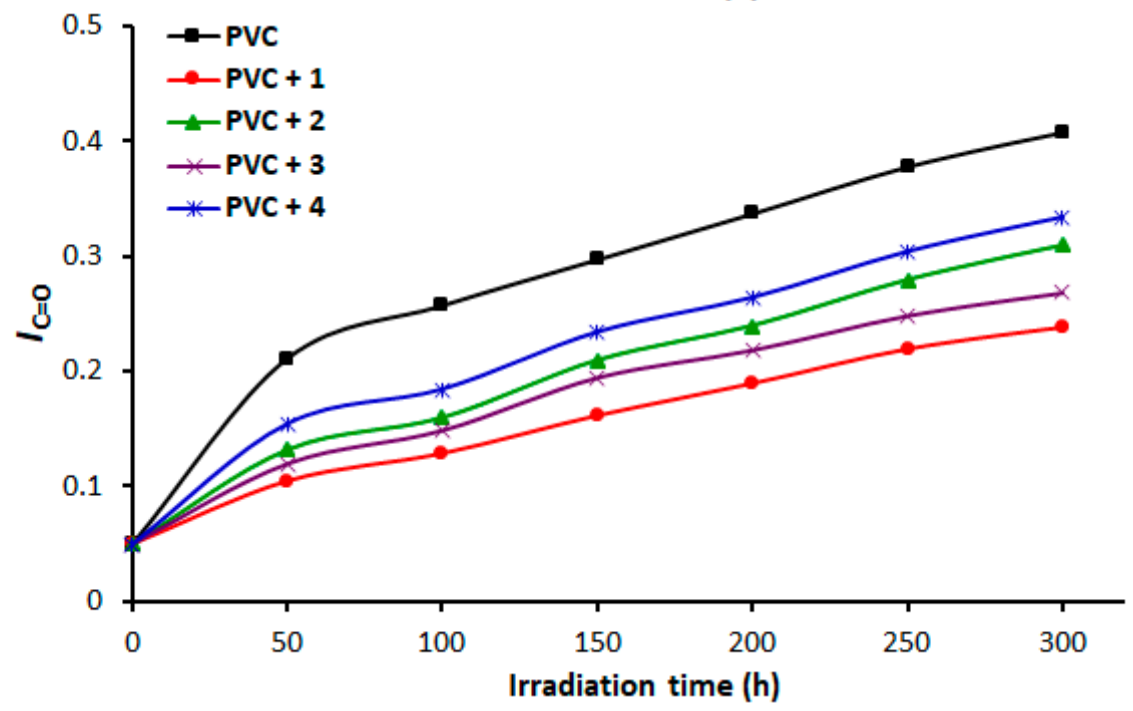

(c)

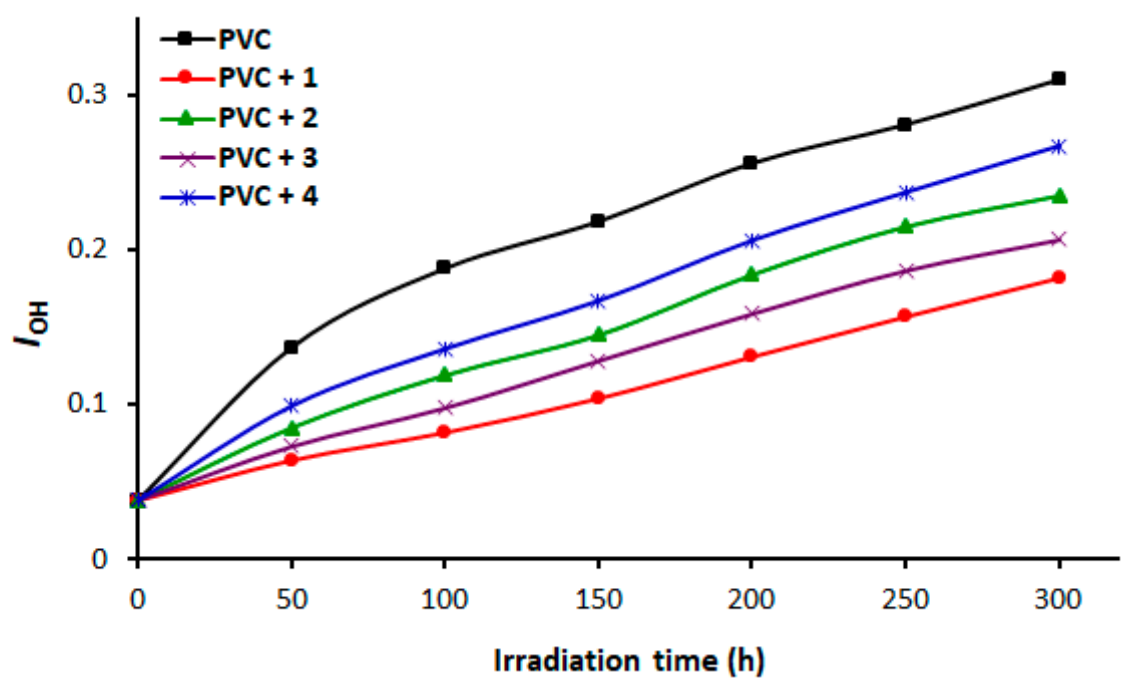

Figure 2. Changes in the functional group indices of Poly(vinyl chloride) (PVC) films (a) $I_{\mathrm{C}=\mathrm{C}}$, (b) $I_{\mathrm{C}=\mathrm{O}}$, and (c) $I_{\mathrm{OH}}$. 


\subsection{PVC Photodegradation Using Weight Loss}

Long-term exposure of PVC films to UV irradiation eliminates several by-products, such as volatiles $($ e.g., $\mathrm{HCl}$ ) and small fragments with a low molecular weight [48]. Therefore, depending on the duration of exposure, irradiation of PVC causes a loss in the weight of the material [49]. We calculated the PVC weight loss due to irradiation using Equation (2) and plotted it as a function of time (Figure 3). As the duration of irradiation increased, the progression of the weight loss was sharp and steady increased, and it was more significant for the blank PVC material. At the end of the irradiation process $(300 \mathrm{~h})$, the percent weight losses of PVC were $3.2 \%, 1.7 \%, 2.2 \%, 2.0 \%$, and $2.4 \%$ for pure PVC film, PVC $/ \mathbf{1}, \mathrm{PVC} / \mathbf{2}$, $\mathrm{PVC} / 3$, and PVC/4 blends, respectively. The lowest PVC weight loss was observed when 1 was used as an additive.

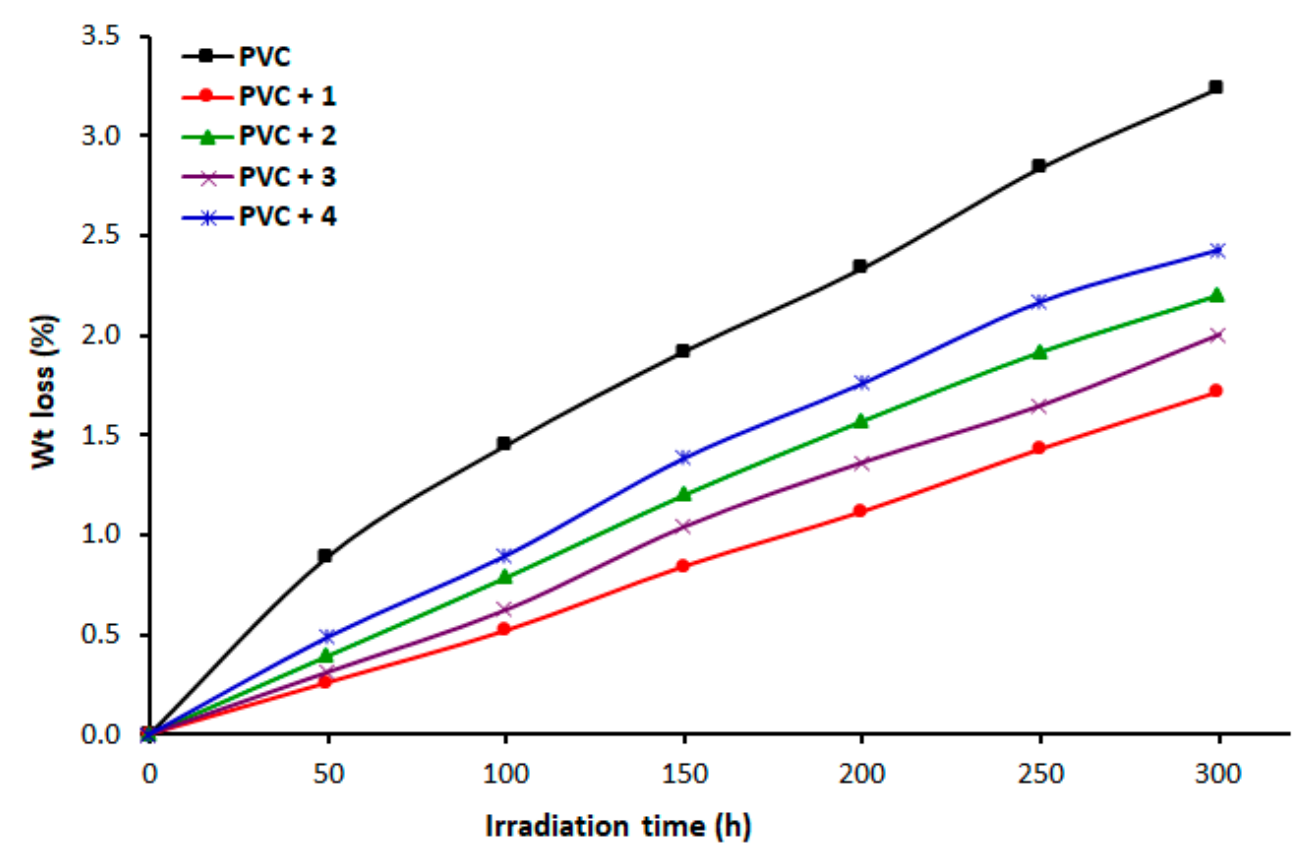

Figure 3. Changes in the weight of PVC films.

\subsection{Surface Morphology of PVC Films}

Long-term irradiation of PVC causes damage and the appearance of defects and irregularities in the surface of the material [50]. The damage results primarily from dehydrochlorination and chain scission [51]. In the current study, the surface of PVC before irradiation was generally smooth and regular [51]. The microscopic images of PVC films after irradiation $(300 \mathrm{~h}$ ) revealed the formation of grooves, spots, cracks, and a color change (Figure 4). However, for the PVC/tin complex blends, the damage was less significant than that seen in the surface of pure PVC film. The additives reduced the rate of elimination of $\mathrm{HCl}$ from $\mathrm{PVC}$ and, therefore, improved the photostability of the polymer. 
(a)

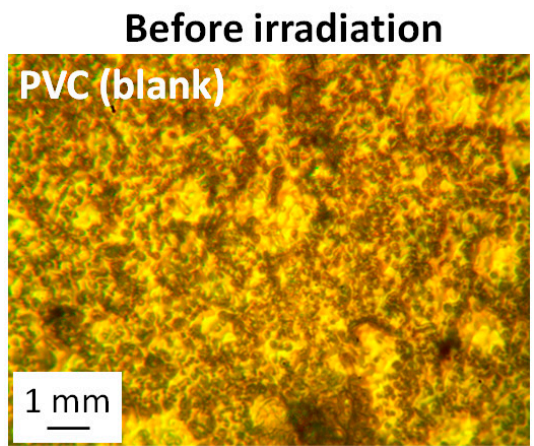

(b)

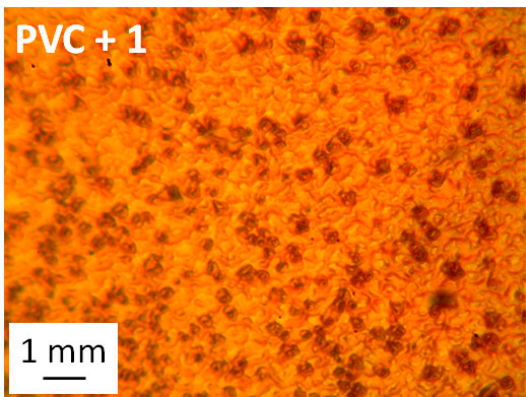

(c)

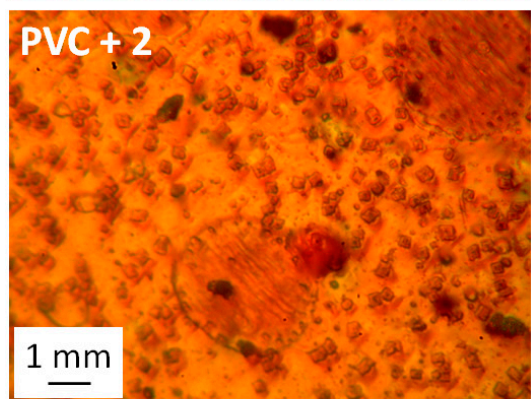

(d)
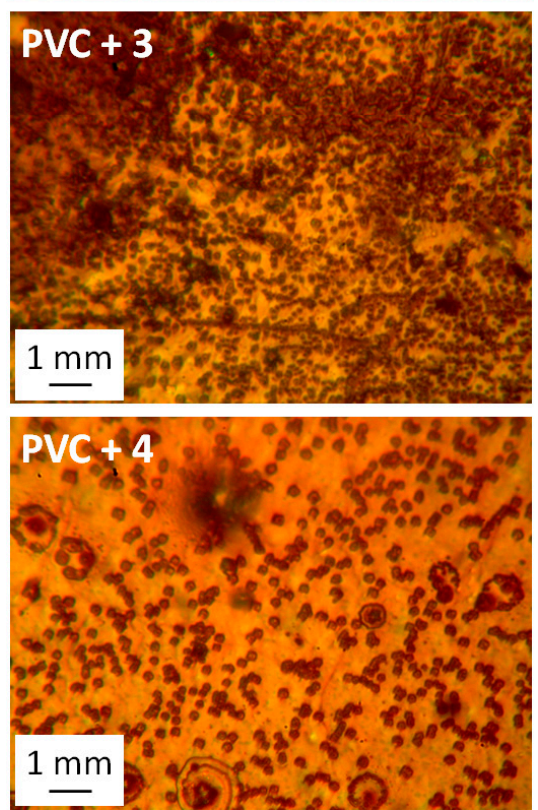
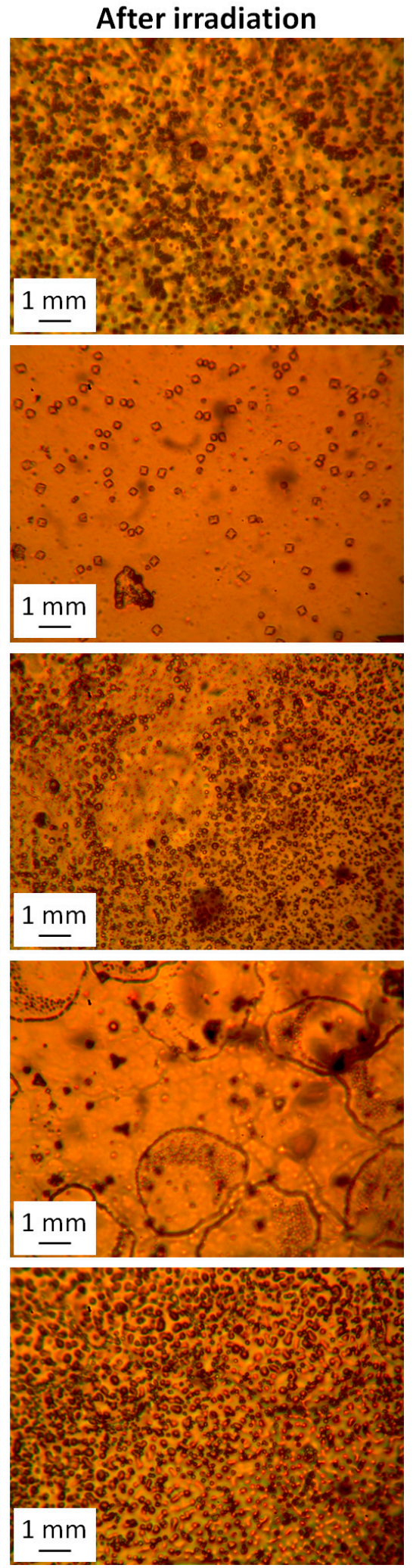

Figure 4. Microscope images (1 mm) of: (a) pure PVC, and (b) PVC/1, (c) PVC/2, (d) PVC/3, and (e) $\mathrm{PVC} / 4$ blends both before and after irradiation.

We inspected the PVC surface morphology further, using a Field Emission Scanning Electron Microscope (FESEM). A FESEM yields high-resolution images that provide detailed information about the homogeneity, shape, cross-sections, and particle sizes of 
materials $[52,53]$. FESEM images of non-irradiated PVC generally reveal a smooth and homogenous surface [54]. In this study, the FESEM image (Figure 5a) of non-irradiated PVC (blank) revealed a regular, homogenous, and smooth surface. Moreover, the particles were of similar size and shape. However, the PVC surface of the blends, after irradiation were significantly damaged (Figure 5b-f). Cracks, cavities, spots, irregularities, and variations in the sizes and shapes of particles were more clearly visible on the surface of irradiated pure PVC film (Figure 5b). Such damage and irregularities resulted mainly due to chain cross-linking and elimination of $\mathrm{HCl}$ and other small molecules [55]. The findings show that the additives used, particularly additive 1, significantly reduced the rate of both cross-linking and dehydrochlorination (Figure 5).
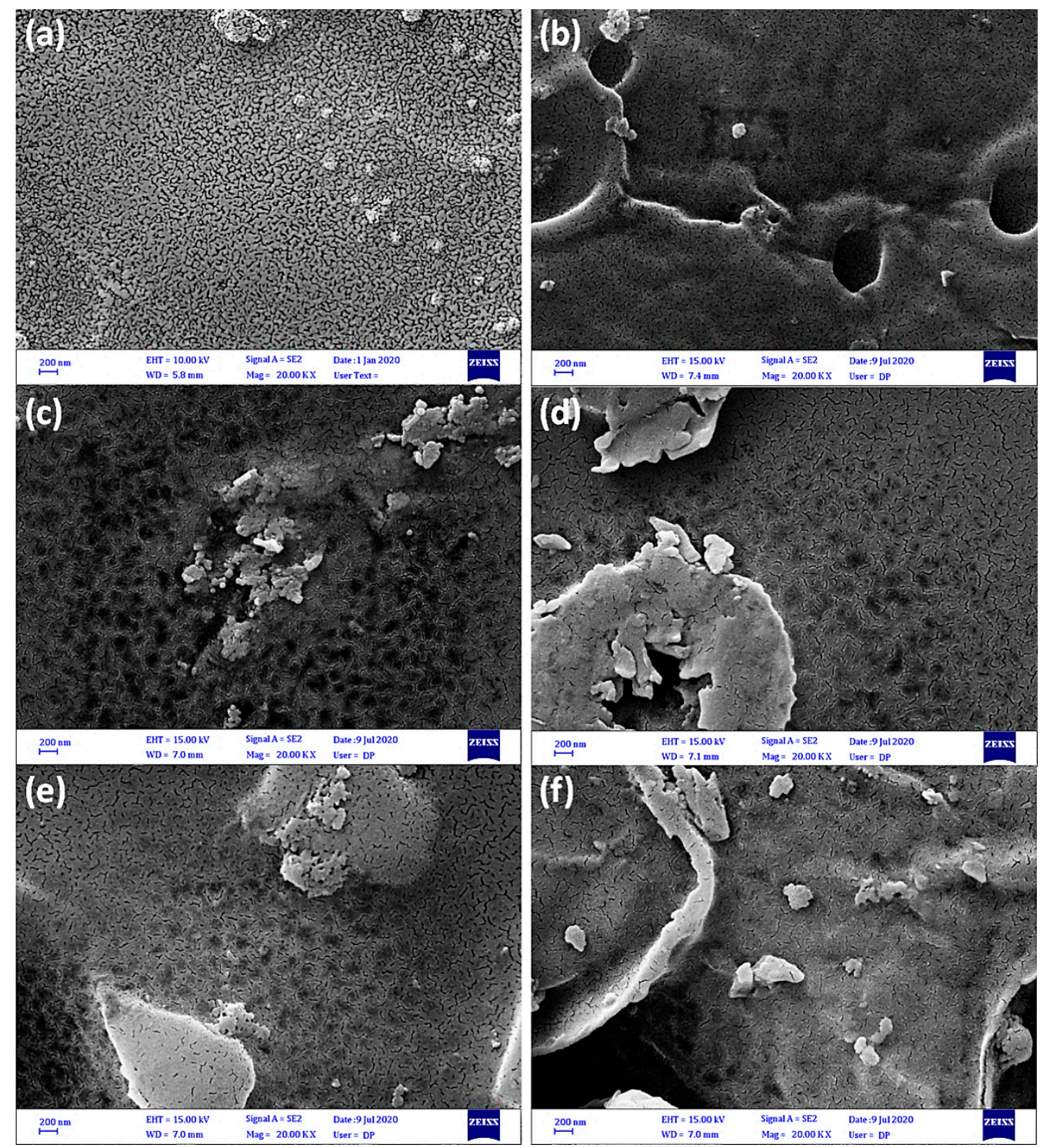

Figure 5. FESEM images of: (a) PVC before irradiation, and (b) PVC, (c) PVC/1, (d) PVC/2, (e) PVC/3, and (f) PVC/4 films after 300 hours of irradiation.

We also used an atomic force microscope (AFM) to provide clear topographic images of the irradiated PVC films. The AFM images indicated that the surfaces of irradiated PVC film were less smooth than they were before irradiation (Figure 6). We analyzed the smoothness of the PVC surface using the roughness factor $(R q)$. A high $R q$ indicates a low degree of smoothness and considerable irregularity due to dehydrochlorination and bondbreaking of polymeric chains [6]. After irradiation, the surface of PVC/1 film exhibited a 
high degree of smoothness $(R q=36.3)$. Conversely, the blank PVC film exhibited a high degree of roughness and irregularities $(R q=232.0)$ after irradiation. It is evident that complex 1 improved the smoothness of the PVC surface 6.4 -fold. The $R q$ of the irradiated PVC/2, PVC/3, and PVC/4 films was 42.2, 44.5, and 137.7, respectively. The additives used provided superior PVC photostabilization to that provided by tin complexes containing 2-(4-Isobutylphenyl)propanoate [56] and naproxen [27], and by Schiff bases containing melamine [15] and triazol-3-thiol [19], and their performance was comparable to that of the tin complex containing furosemide [29].

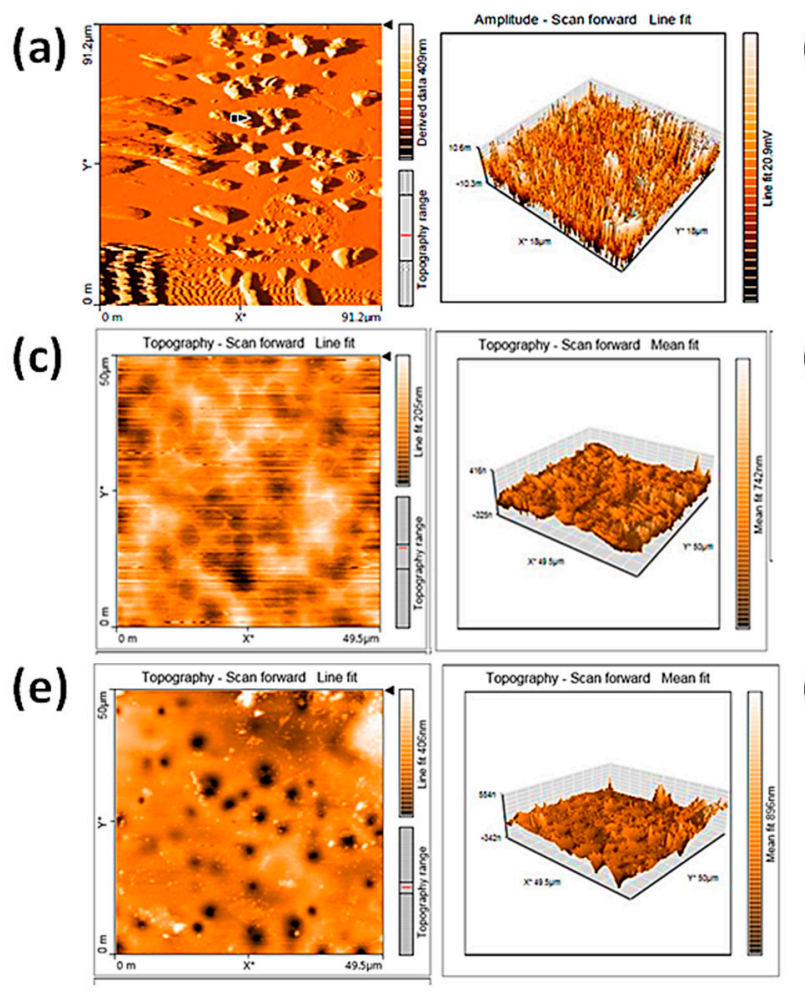

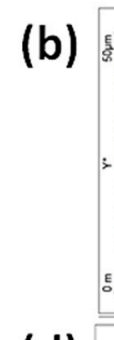

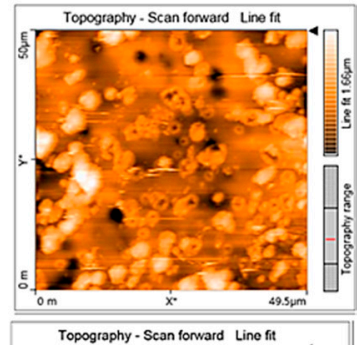

(d)
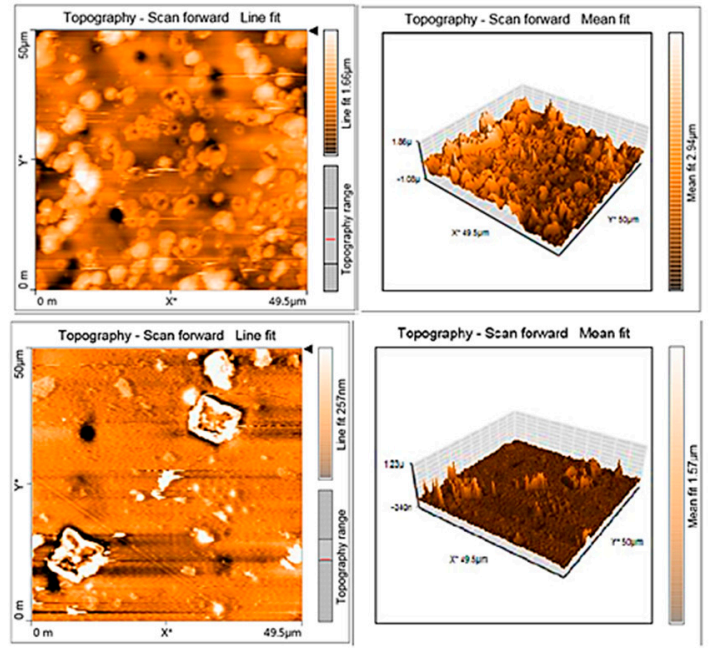

(f)
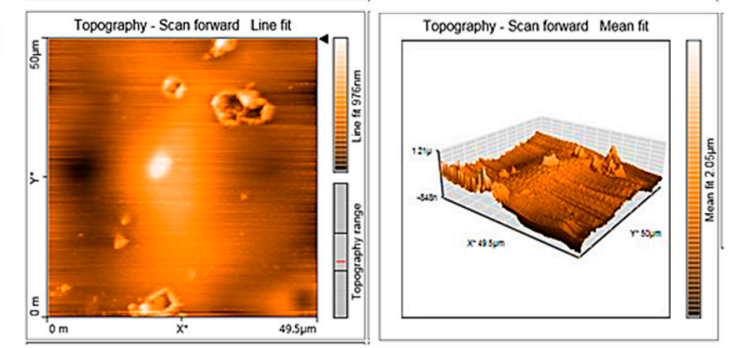

Figure 6. Atomic force microscope (AFM) images of: (a) PVC before irradiation, and (b) PVC, (c) PVC/1, (d) PVC/2, (e) PVC/3, and (f) PVC/4 films after $300 \mathrm{~h}$ of irradiation.

The energy-dispersive X-ray (EDX) spectra of PVC blends with tin complexes (Figure 7) revealed new bands corresponding to tin, nitrogen, and oxygen, in addition to carbon and chlorine atoms (high proportion). After irradiation, the carbon content of PVC films increased along with a decrease in chlorine content. The reduction in the chlorine content indicates the elimination of $\mathrm{HCl}$ due to photodegradation and photooxidation of PVC. After irradiation, the PVC films containing additives had a higher percentage of chlorine than had with the pure PVC materials. Figure 7 shows the abundance of elements PVC blends after irradiation. 

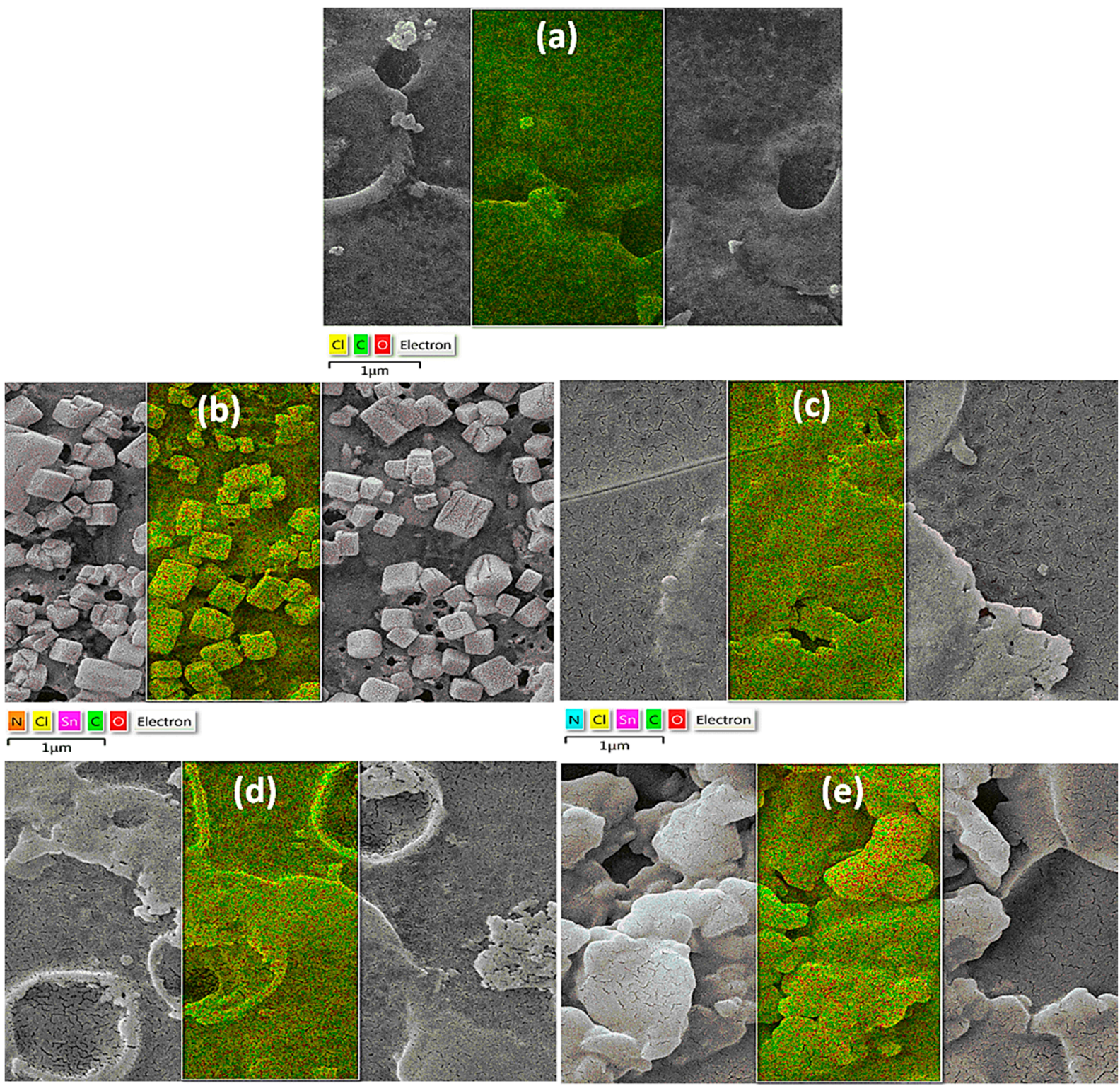

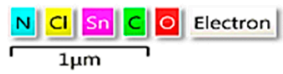

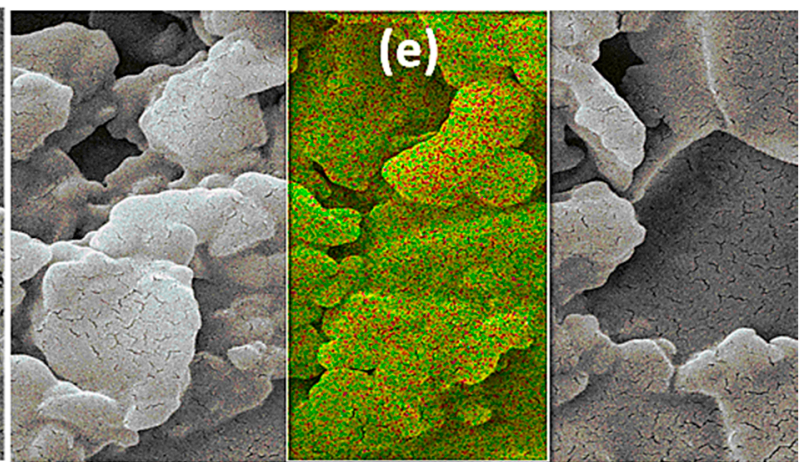

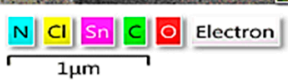

Figure 7. Energy-dispersive X-ray (EDX) mapping of: (a) pure PVC film, and (b) PVC/1, (c) PVC/2, (d) PVC/3, and (e) PVC / 4 blends after $300 \mathrm{~h}$ of irradiation.

\subsection{PVC Photostabilization Proposed Mechanisms}

Additives 1-4 are shown to be good photostabilizers of PVC, protecting against photodecomposition, and photooxidation of the material, upon exposure to irradiation. The organotin $\mathbf{1}$ was the most effective additive as photostabilizers of PVC. Additive 1 is highly aromatic, as it contains three phenyl rings in addition to the aryl rings within the skeleton of carvedilol. Additives 2 and $\mathbf{3}$ contain $n$-butyl groups, whereas additive 4 contains methyl groups. In this study, these additives, particularly additive $\mathbf{1}$, acted as UV absorbers, peroxide decomposers, and radical scavengers [14,29,56-59]. Furthermore, the additives contain the highly acidic tin atom (Lewis acid), they act as excellent scavengers of $\mathrm{HCl}$ (Figure 8) $[57,60]$. The low concentration of $\mathbf{1}-\mathbf{4}$ within the polymeric matrix minimizes any harmful effects of additives when irradiated [60]. Moreover, the coordination between PVC polarized bonds $(\mathrm{C}-\mathrm{Cl})$ and electron-rich atoms (e.g., oxygen) in carvedilol stabilize polymeric chains through the transference of energy [29]. 


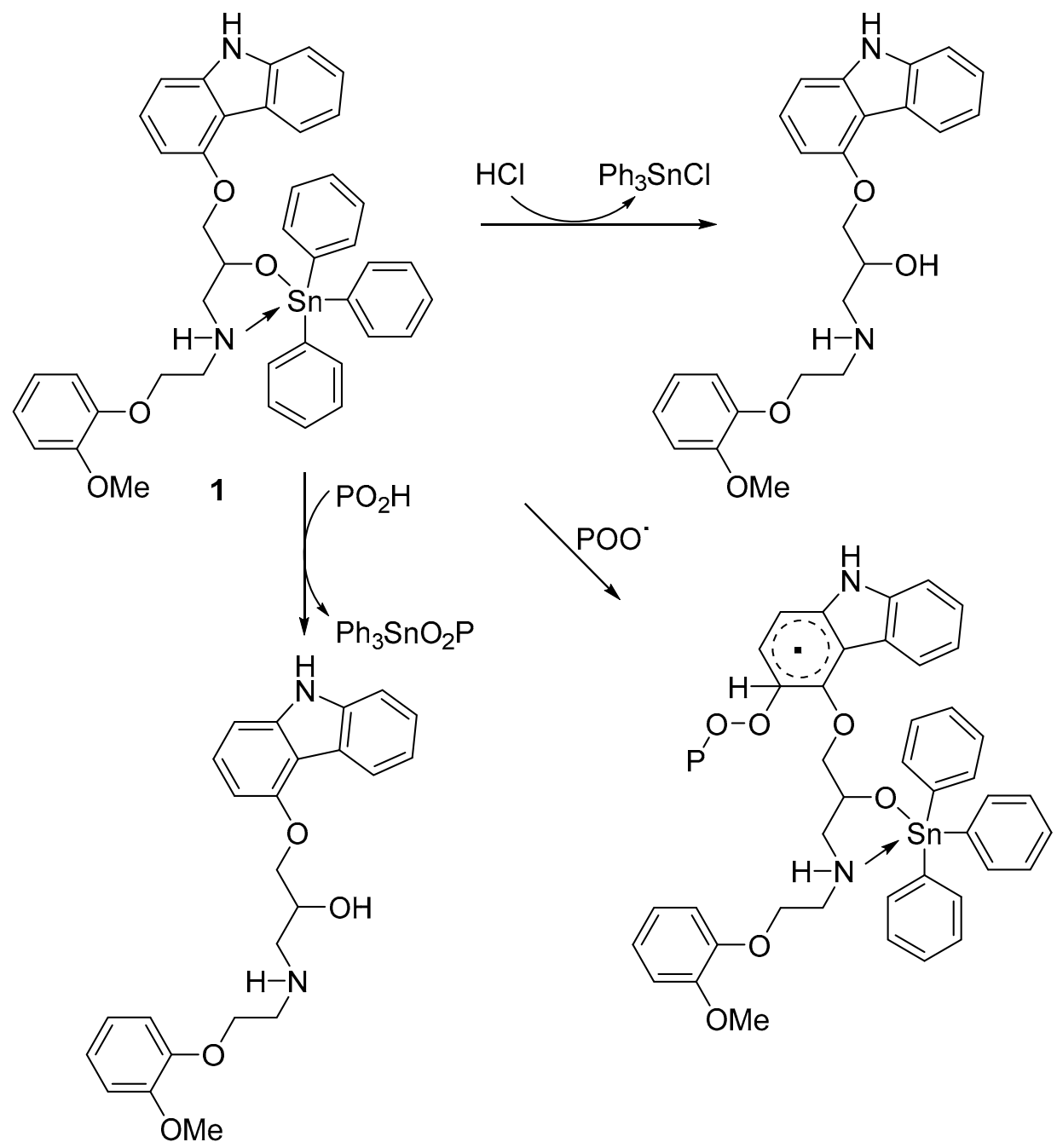

Figure 8. Complex 1 acts as a scavenger of peroxides, radicals, and hydrogen chloride.

\section{Conclusions}

In this study, simple procedures are used to synthesize high yields of several organotin complexes. We analyzed the effect of organotin complexes as inhibitors of PVC photodegradation. Irradiation of thin films of PVC produces destructive changes in the infrared spectra due to the formation of small fragments containing functional groups, loss of weight of the material, and surface defects in the PVC caused by photodegradation. In the presence of tin complexes, such changes were less significant than those that occurred in the blank PVC film. As the concentrations of the additives used were low, their use did not result in changes in either color or homogeneity. The additives used enhanced the photostability of PVC significantly, and the additive with a high degree of aromaticity was particularly effective. Such additives act as absorbers of UV irradiation and scavengers of hydrogen chloride, peroxides, and radicals.

Author Contributions: Conceptualization and experimental design: G.A.E.-H., M.A.B., M.B., A.A., A.A.A., D.S.A., and E.Y.; Experimental work and data analysis: O.G.M.; writing: G.A.E.-H., D.S.A., and E.Y. All authors have read and agreed to the published version of the manuscript.

Funding: The authors are grateful to the Deanship of Scientific Research, King Saud University for funding through Vice Deanship of Scientific Research Chairs.

Acknowledgments: We thank Tikrit and Al-Nahrain Universities for technical support. 
Conflicts of Interest: The authors declare no conflict of interest. The funders had no role in the design of the study; in the collection, analyses, or interpretation of data; in the writing of the manuscript, or in the decision to publish the results.

\section{References}

1. Feldman, D. Polymer history. Des. Monomers Polym. 2008, 11, 1-15. [CrossRef]

2. Burgess, R.H. Manufacture and Processing of PVC; Elsevier Applied Science Publishers Ltd: London, UK, 2005.

3. Titow, W.V. PVC Plastics Properties, Processing, and Applications; Elsevier Applied Science Publishers Ltd: London, UK, 1990.

4. Abu Bakar, A.; Hassan, A.; Yusof, A.F.M. Mechanical properties of silane and zirconate coupling agent-treated oil palm empty fruit bunch fiber-filled acrylic-impact modified poly (vinyl chloride) composites. Polym. Plast. Technol. Eng. 2010, 49, 1563-1570. [CrossRef]

5. Porta, M.; Zumeta, E. Implementing the Stockholm treaty on persistent organic pollutants. Occup. Environ. Med. 2002, 59, 651-652. [CrossRef]

6. Zheng, X.G.; Tang, L.H.; Zhang, N.; Gao, Q.H.; Zhang, C.F.; Zhu, Z.B. Dehydrochlorination of PVC materials at high temperature. Energy Fuels 2003, 17, 896-900. [CrossRef]

7. Yousif, E.; Hasan, A. Photostabilization of poly(vinyl chloride)—Still on the run. J. Taibah Uiv. Sci. 2015, 9, 421-448. [CrossRef]

8. Gao, A.X.; Bolt, J.D.; Feng, A.A. Role of titanium dioxide pigments in outdoor weathering of rigid PVC. Plast. Rubber Compos. 2008, 37, 397-402. [CrossRef]

9. Chai, R.D.; Zhang, J. Synergistic effect of hindered amine light stabilizers/ultraviolet absorbers on the polyvinyl chloride/powder nitrile rubber blends during photodegradation. Polym. Eng. Sci. 2013, 53, 1760-1769. [CrossRef]

10. Cadogan, D.F.; Howick, C.J. Plasticizers. In Ullmann's Encyclopedia of Industrial Chemistry; Wiley-VCH: Weinheim, Germany, 2000.

11. El-Hiti, G.A.; Ahmed, D.S.; Yousif, E.; Alotaibi, M.H.; Star, H.A.; Ahmed, A.A. Influence of polyphosphates on the physicochemical properties of poly(vinyl chloride) after irradiation with ultraviolet light. Polymers 2020, 12, 193. [CrossRef] [PubMed]

12. Ahmed, D.S.; El-Hiti, G.A.; Yousif, E.; Hameed, A.S. Polyphosphates as inhibitors for poly(vinyl chloride) photodegradation. Molecules 2017, 22, 1849. [CrossRef]

13. Sabaa, M.W.; Oraby, E.H.; Abdel Naby, A.S.; Mohammed, R.R. Anthraquinone derivatives as organic stabilizers for rigid poly(vinyl chloride) against photo-degradation. Eur. Polym. J. 2005, 41, 2530-2543. [CrossRef]

14. Balakit, A.A.; Ahmed, A.; El-Hiti, G.A.; Smith, K.; Yousif, E. Synthesis of new thiophene derivatives and their use as photostabilizers for rigid poly(vinyl chloride). Int. J. Polym. Sci. 2015, 2015, 510390. [CrossRef]

15. El-Hiti, G.A.; Alotaibi, M.H.; Ahmed, A.A.; Hamad, B.A.; Ahmed, D.S.; Ahmed, A.; Hashim, H.; Yousif, E. The morphology and performance of poly(vinyl chloride) containing melamine Schiff bases against ultraviolet light. Molecules 2019, 24, 803. [CrossRef] [PubMed]

16. Ahmed, A.A.; Ahmed, D.S.; El-Hiti, G.A.; Alotaibi, M.H.; Hashim, H.; Yousif, E. SEM morphological analysis of irradiated polystyrene film doped by a Schiff base containing a 1,2,4-triazole ring system. Appl. Petrochem. Res. 2019, 9, 169-177. [CrossRef]

17. Shaalan, N.; Laftah, N.; El-Hiti, G.A.; Alotaibi, M.H.; Muslih, R.; Ahmed, D.S.; Yousif, E. Poly(vinyl chloride) photostabilization in the presence of Schiff bases containing a thiadiazole moiety. Molecules 2018, 23, 913. [CrossRef]

18. Ahmed, D.S.; El-Hiti, G.A.; Hameed, A.S.; Yousif, E.; Ahmed, A. New tetra-Schiff bases as efficient photostabilizers for poly(vinyl chloride). Molecules 2017, 22, 1506. [CrossRef] [PubMed]

19. Yousif, E.; Hasan, A.; El-Hiti, G.A. Spectroscopic, physical and topography of photochemical process of PVC films in the presence of Schiff base metal complexes. Polymers 2016, 8, 204. [CrossRef]

20. Schiller, M. PVC Additives: Performance, Chemistry, Developments, and Sustainability; Carl Hanser Verlag: Munich, Germany, 2015.

21. Yang, T.C.T.; Noguchi, T.; Isshiki, M.; Wu, J.H. Effect of titanium dioxide particles on the surface morphology and the mechanical properties of PVC composites during QUV accelerated weathering. Polym. Compos. 2016, 37, 3391-3397. [CrossRef]

22. Yang, T.C.; Noguchi, T.; Isshiki, M.; Wu, J.H. Effect of titanium dioxide on chemical and molecular changes in PVC sidings during QUV accelerated weathering. Polym. Degrad. Stab. 2014, 104, 33-39. [CrossRef]

23. Mahmood, Z.N.; Yousif, E.; Alias, M.; El-Hiti, G.A.; Ahmed, D.S. Synthesis, characterization, properties, and use of new fusidate organotin complexes as additives to inhibit poly(vinyl chloride) photodegradation. J. Polym. Res. 2020, 27, 267. [CrossRef]

24. Ahmed, D.S.; El-Hiti, G.A.; Ibraheem, H.; Alotaibi, M.H.; Abdallh, M.; Ahmed, A.A.; Ismael, M.; Yousif, E. Enhancement of photostabilization of poly(vinyl chloride) doped with sulfadiazine tin complexes. J. Vinyl Addit. Techn. 2020, 25, 370-379. [CrossRef]

25. Mohammed, A.; El-Hiti, G.A.; Yousif, E.; Ahmed, A.A.; Ahmed, D.S.; Alotaibi, M.H. Protection of poly(vinyl chloride) films against photodegradation using various valsartan tin complexes. Polymers 2020, 12, 969. [CrossRef]

26. Hadi, A.G.; Jawad, K.; El-Hiti, G.A.; Alotaibi, M.H.; Ahmed, A.A.; Ahmed, D.S.; Yousif, E. Photostabilization of poly(vinyl chloride) by organotin(IV) compounds against photodegradation. Molecules 2019, 24, 3557. [CrossRef]

27. Hadi, A.G.; Yousif, E.; El-Hiti, G.A.; Ahmed, D.S.; Jawad, K.; Alotaibi, M.H.; Hashim, H. Long-term effect of ultraviolet irradiation on poly(vinyl chloride) films containing naproxen diorganotin(IV) complexes. Molecules 2019, 24, 2396. [CrossRef]

28. Ghazi, D.; El-Hiti, G.A.; Yousif, E.; Ahmed, D.S.; Alotaibi, M.H. The effect of ultraviolet irradiation on the physicochemical properties of poly(vinyl chloride) films containing organotin(IV) complexes as photostabilizers. Molecules 2018, 23, 254. [CrossRef] [PubMed] 
29. Ali, M.M.; El-Hiti, G.A.; Yousif, E. Photostabilizing efficiency of poly(vinyl chloride) in the presence of organotin(IV) complexes as photostabilizers. Molecules 2016, 21, 1151. [CrossRef]

30. Adeyemi, J.O.; Onwudiwe, D.C. Organotin(IV) dithiocarbamate complexes: Chemistry and biological activity. Molecules 2018, 23, 2571. [CrossRef] [PubMed]

31. Khan, N.; Farina, Y.; Mun, L.K.; Rajab, N.F.; Awang, N. Syntheses, characterization, X-ray diffraction studies and in vitro antitumor activities of diorganotin(IV) derivatives of bis( $p$-substituted-N-methylbenzylaminedithiocarbamates). Polyhedron 2015, 85, 754-760. [CrossRef]

32. Gaumet, S.; Gardette, J.-L. Photo-oxidation of poly(vinyl chloride): Part 2-A comparative study of the carbonylated products in photo-chemical and thermal oxidations. Polym. Degrad. Stab. 1991, 33, 17-34. [CrossRef]

33. Bacchi, A.; Bonardi, A.; Carcelli, M.; Mazza, P.; Pelagatti, P.; Pelizzi, C.; Pelizzi, G.; Solinas, C.; Zani, F. Organotin complexes with pyrrole-2,5-dicarboxaldehyde bis(acylhydrazones). Synthesis, structure, antimicrobial activity and genotoxicity. J. Inorg. Biochem. 1998, 69, 101-112. [CrossRef]

34. Al-Jibouri, M.N.A.; Al-Ameri, S.A.H.; Al-Jibouri, W.M.; Al-Souz, M.A.K. Spectroscopic study of the effect of a new metal chelate on the stability of PVC. J. Assoc. Arab Univ. Basic Appl. Sci. 2013, 14, 67-74. [CrossRef]

35. Tarafder, M.T.H.; Chew, K.-B.; Crouse, K.A.; Ali, M.A.; Yamin, B.M.; Fun, H.-K. Synthesis and characterization of Cu(II), Ni(II) and $\mathrm{Zn}(\mathrm{II})$ metal complexes of bidentate NS isomeric Schiff bases derived from S-methyldithiocarbazate (SMDTC): Bioactivity of the bidentate NS isomeric Schiff bases, some of their $\mathrm{Cu}(\mathrm{II}), \mathrm{Ni}(\mathrm{II})$ and $\mathrm{Zn}(\mathrm{II})$ complexes and the X-ray structure of the bis[S-methyl- $\beta$ - $N$-(2-furyl-methyl)methylenedithiocarbazato]zinc(II) complex. Polyhedron 2002, 21, 2683-2690. [CrossRef]

36. Morozov, O.S.; Vyshinskii, N.N.; Rudnevskii, N.K. Investigation of some organotin compounds and their complexes by IR spectroscopy. J. Appl. Spectrosc. 1981, 35, 1019-1023. [CrossRef]

37. Masood, H.; Ali, S.; Mazhar, M.; Shahzadi, S.; Shahid, K. ${ }^{1} \mathrm{H},{ }^{13} \mathrm{C},{ }^{119} \mathrm{Sn}$ NMR, Mass, Mössbauer and biological studies of tri-, diand chlorodiorganotin(IV) carboxylates. Turk. J. Chem. 2004, 28, 75-86.

38. Shahid, K.; Ali, S.; Shahzadi, S.; Badshah, A.; Khan, K.M.; Maharvi, G.M. Organotin(IV) complexes of aniline derivatives. I. Synthesis, spectral and antibacterial studies of di- and triorganotin(IV) derivatives of 4-bromomaleanilic acid. Synth. React. Inorg. Met Org. Chem. 2003, 33, 1221-1235. [CrossRef]

39. Rehman, W.; Baloch, M.K.; Badshah, A.; Ali, S. Synthesis and characterization of biologically potent di-organotin(IV) complexes of mono-methyl glutarate. J. Chin. Chem. Soc. 2005, 52, 231-236. [CrossRef]

40. Salam, M.A.; Affan, M.A.; Arafat, M.A.; Saha, R.; Nasrin, R. Synthesis, characterization, and antibacterial activities of organotin(IV) complexes with 2-acetylpyridine-N(4)-cyclohexylthiosemicarbazone (HAPCT). Heteroatom Chem. 2013, 24, 43-52. [CrossRef]

41. Srinivas, P.; Suresh, T.; Revanasiddappa, M.; Khasim, S. Synthetic, spectral and thermal studies of tin(IV) complexes of 1,5benzodiazepines. J. Chem. 2008, 5, 627-633. [CrossRef]

42. Chee, D.N.A.; Affan, M.A.; Ahmad, F.B.; Asaruddin, M.R.; Sam, N.; Salam, M.A.; Ismail, A.; Tan, S.H. Synthesis, characterization, and antibacterial activity of organotin(IV) complexes with 2-hydroxyacetophenone thiocarbohydrazone. J. Coord. Chem. 2011, 64, 4191-4200. [CrossRef]

43. Andrady, A.; Searle, N. Photodegradation of rigid PVC formulations. II. Spectral sensitivity to light-induced yellowing by polychromatic light. J. Appl. Polym. Sci. 1989, 37, 789-2802. [CrossRef]

44. Gardette, J.L.; Gaumet, S.; Lemaire, J. Photooxidation of poly(vinyl chloride). 1. A reexamination of the mechanism. Macromolecules 1989, 22, 2576-2581. [CrossRef]

45. Almond, J.; Sugumaar, P.; Wenzel, M.N.; Hill, G.; Wallis, C. Determination of the carbonyl index of polyethylene and polypropylene using specified area under band methodology with ATR-FTIR spectroscopy. e-Polymers 2020, 20, 369-381. [CrossRef]

46. Rabek, J.F.; Shur, Y.J.; Rårnby, B. Studies of the photooxidation mechanism of polymers. III. Role of tetrahydrofuran in the photooxidative degradation of poly(vinyl chloride). J. Polym. Sci. Pol. Chem. 1975, 13, 1285-1295. [CrossRef]

47. Mehmandoust, S.G.; Sokhandani, P.; Abdi, A.M.; Babaluo, A.A.; Alizadeh, R. Effect of long time exposure on the chemical and physical properties of polyvinyl chloride/titanium dioxide nanocomposites. J. Thermoplast. Compos. Mater. 2016, 29, 1498-1516. [CrossRef]

48. Jafari, A.J.; Donaldson, J.D. Determination of $\mathrm{HCl}$ and VOC emission from thermal degradation of PVC in the absence and presence of copper, copper(II) oxide and copper(II) chloride. J. Chem. 2009, 6, 685-692. [CrossRef]

49. Rabie, S.T.; Ahmed, A.E.; Sabaa, M.W.; Abd El-Ghaar, M.A. Maleic diamides as photostabilizers for polystyrene. J. Ind. Eng. Chem. 2013, 19, 1869-1878. [CrossRef]

50. Valko, L.; Klein, E.; Kovařík, P.; Bleha, T.; Šimon, P. Kinetic study of thermal dehydrochlorination of poly(vinyl chloride) in the presence of oxygen: III. Statistical thermodynamic interpretation of the oxygen catalytic activity. Eur. Polym. J. 2001, 37, 1123-1132. [CrossRef]

51. Yousif, E.; El-Hiti, G.A.; Hussain, Z.; Altaie, A. Viscoelastic, spectroscopic and microscopic study of the photo irradiation effect on the stability of PVC in the presence of sulfamethoxazole Schiff's bases. Polymers 2015, 7, 2190-2204. [CrossRef]

52. Hashim, H.; El-Hiti, G.A.; Alotaibi, M.H.; Ahmed, D.S.; Yousif, E. Fabrication of ordered honeycomb porous poly(vinyl chloride) thin film doped with a Schiff base and nickel(II) chloride. Heliyon 2018, 4, e00743. [CrossRef] [PubMed]

53. Nikafshar, S.; Zabihi, O.; Ahmadi, M.; Mirmohseni, A.; Taseidifar, M.; Naebe, M. The effects of UV light on the chemical and mechanical properties of a transparent epoxy-diamine system in the presence of an organic UV absorber. Materials 2017, 10, 180. [CrossRef] 
54. Alotaibi, M.H.; El-Hiti, G.A.; Yousif, E.; Ahmed, D.S.; Hashim, H.; Hameed, A.S.; Ahmed, A. Evaluation of the use of polyphosphates as photostabilizers and in the formation of ball-like polystyrene materials. J. Polym. Res. 2019, 26, 161. [CrossRef]

55. Shi, W.; Zhang, J.; Shi, X.-M.; Jiang, G.-D. Different photodegradation processes of PVC with different average degrees of polymerization. J. Appl. Polym. Sci. 2008, 107, 528-540. [CrossRef]

56. Mohammed, R.; El-Hiti, G.A.; Ahmed, A.; Yousif, E. Poly(vinyl chloride) doped by 2-(4-isobutylphenyl)propanoate metal complexes: Enhanced resistance to UV irradiation. Arab. J. Sci. Eng. 2017, 42, 4307-4315. [CrossRef]

57. Folarin, O.M.; Sadiku, E.R. Thermal stabilizers for poly(vinyl chloride): A review. Int. J. Phys. Sci. 2011, 6, 4323-4330. [CrossRef]

58. Sabaa, M.W.; Oraby, E.H.; Naby, A.A.S.; Mohamed, R.R. N-Phenyl-3-substituted-5-pyrazolone derivatives as organic stabilizer for rigid PVC against photodegradation. J. Appl. Polym. Sci. 2005, 101, 1543-1555. [CrossRef]

59. Nief, O.A. Photostabilization of polyvinyl chloride by some new thiadiazole derivatives. Eur. J. Chem. 2015, 6, 242-247. [CrossRef]

60. Xiang, X.; Chen, S.; Chai, R. Photodegradation of plasticized poly(vinyl chloride) stabilized by different types of thermal stabilizers. Polym. Eng. Sci. 2011, 51, 624-631. [CrossRef] 